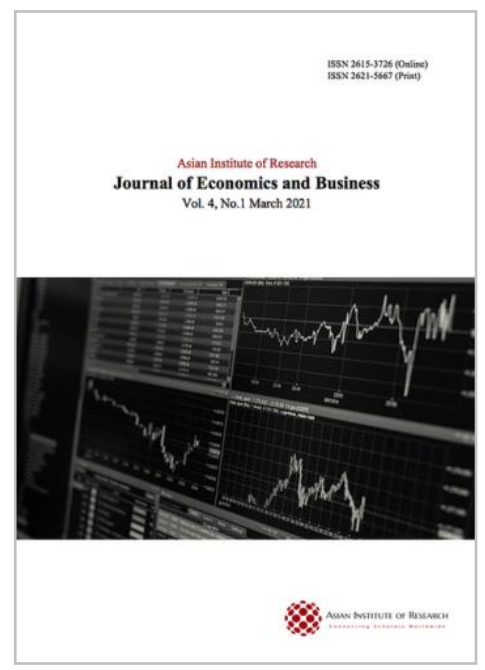

\title{
Journal of Economics
} and Business

Kamajaya, Audia Putri, and Aribowo, Agus. (2021), The Effect of Perceived Value and Service Quality on Depositor Loyalty. In: Journal of Economics and Business, Vol.4, No.1, 183-192.

ISSN 2615-3726

DOI: 10.31014/aior.1992.04.01.330

The online version of this article can be found at: https://www.asianinstituteofresearch.org/

Published by:

The Asian Institute of Research

The Journal of Economics and Business is an Open Access publication. It may be read, copied, and distributed free of charge according to the conditions of the Creative Commons Attribution 4.0 International license.

The Asian Institute of Research Journal of Economics and Business is a peer-reviewed International Journal. The journal covers scholarly articles in the fields of Economics and Business, which includes, but not limited to, Business Economics (Micro and Macro), Finance, Management, Marketing, Business Law, Entrepreneurship, Behavioral and Health Economics, Government Taxation and Regulations, Financial Markets, International Economics, Investment, and Economic Development. As the journal is Open Access, it ensures high visibility and the increase of citations for all research articles published. The Journal of Economics and Business aims to facilitate scholarly work on recent theoretical and practical aspects of Economics and Business. 


\title{
The Effect of Perceived Value and Service Quality on Depositor Loyalty
}

\author{
Audi Putri Kamajaya ${ }^{1}$, Agus Aribowo ${ }^{2}$
}

\begin{abstract}
${ }^{1}$ Department of Master of Management of Business Faculty, Maranatha Christian University Bandung, INDONESIA. Email: audiaputrikamajaya@gmail.com ${ }^{2}$ Department of Master of Management of Business Faculty, Maranatha Christian University Bandung, INDONESIA. Email: aribowoagus@yahoo.com
\end{abstract}

\begin{abstract}
For a bank, the depositors are the primary assets. Therefore, the bank should maintain a good relationship with them to be loyal to all efforts. If they are faithful, they will always keep putting their money in the bank. Therefore, the bank can execute the intermediate function properly. This study intends to examine the effect of perceived value and service quality on depositor loyalty. Consequently, the depositors of commercial bank $\mathrm{H}$ at branch $\mathrm{F}$ in Bandung become the population and the samples. This study also uses the Slovin formula, simple random sampling, and survey to calculate the samples, grab them, and accumulate the primary data. Moreover, the gathered data get analyzed by the structural equation model (SEM) based on variance. To sum up, this study proves that the perceived value and service quality positively affect depositor loyalty after examining the proposed hypotheses. To increase depositors to be loyal, the bank has to focus on elevating their perceived value and giving them superior service.
\end{abstract}

Keywords: Commercial Bank, Depositor Loyalty, Perceived Value, Service Quality

\section{INTRODUCTION}

A bank performs as an intermediary financial institution in a state economic (Taswan, 2010). Through this role, the bank distributes money from depositors to borrowers in loans; therefore, it can produce profits (Husnan, 2015). To support this condition, the bank marketing staff needs to maintain a relationship with depositors (Chatterjee \& Kamesh, 2019) and attempts to retain them (Narotama, 2019).

As one of the private banks operating in Bandung, Bank $\mathrm{H}$ offers something interesting to time depositors to continually desire to place their money. For example, the bank already gives a higher interest and cashback to them if they add their money for a specific duration. However, this effort makes them, especially in the priority segment ${ }^{1}$, withdraw all money in their deposit saving account in branch office F; for that reason, their status becomes the unqualified depositors. Table one shows the increase in the number of unqualified depositors in the

\footnotetext{
${ }^{1}$ The priority segment is the name given by bank for the group of depositors placing 500 million rupiahs or more.
} 
priority segment from January to December 2019. During this year, this number gets increased from 628 to 657. The highest of 669 is in October. Conversely, the lowest of 628 is in January. This condition makes the bank lose the opportunity to use at least 500 million rupiahs if this status occurs.

Table 1: The number of unqualified depositors (UD) in the priority segment in the year 2019 of Branch $\mathrm{F}$ of Bank $\mathrm{H}$ of in Bandung

\begin{tabular}{|c|c|c|c|c|c|c|c|c|c|c|c|c|}
\hline Month & Jan & Feb & March & April & May & June & July & August & Sept & Oct & Nov & Dec \\
\hline $\begin{array}{l}\text { The number of } \\
\text { UD in priority } \\
\text { segment }\end{array}$ & 628 & 639 & 639 & 637 & 644 & 641 & 647 & 652 & 652 & 669 & 657 & 652 \\
\hline
\end{tabular}

Source: Processed data of Branch F of Bank H

This situation makes the research of the determinants of consumer loyalty in the bank to do. According to the evidence of the previous study, they are perceived value (Jumanev, Kumar, \& Hanaysha, 2012; Hasan, Kiong, \& Ainuddin, 2014; Rahi \& Ghani, 2016; Mukerjee, 2018; Fitri, Basrib, \& Maryanti, 2019) and service quality (Hidayat, Akhmad, \& Mahmud, 2015; Alnaser, Ghani, Rahi, Mansour, \& Abed, 2017; Al-Areqi, Al-Hadeq, \& Mutahar, 2018; Setiawan, Kusumawati, \& Mawardi, 2018). Unfortunately, this indication associated with these determinants does not reach a consensus yet.

- In their research in the banking sector, Jumanev et al. (2012), Hasan et al. (2014), Rahi \& Ghani (2016), Mukerjee (2018), and Fitri et al. (2019) find a positive effect of perceived value on consumer loyalty. Furthermore, Nursiana (2011), Koupai, Alipourdarvish, \& Sardar (2015) find no impact.

- In the same sector, Hidayat et al. (2015), Alnaser et al. (2017), and Al-Areqi et al. (2018) demonstrate a positive effect of service quality on consumer loyalty. However, Setiawan et al. (2018) depict a negative. Moreover, Fitri et al. (2019) and Narotama (2019) display no impact.

The purpose of this study attempts to examine and analyze the effect of perceived value and service quality on the depositor loyalty in this bank branch by considering this contrary evidence. By this study, we expect a clear sign of these two effects. Therefore, the study confirmation can be executed, and the results are expected to help this bank upturn their depositor loyalty.

Perceived value is the ratio between consumers' benefits and cost when consuming company services (Kertajaya, 2007). As shown by Jumanev et al. (2012), as a company, ideally, the banks exist to create and deliver a good perceived value is to make their depositors loyal. This explanation obtains support from other scholars, such as Hasan et al. (2014), Rahi \& Ghani (2016), Mukerjee (2018), and Fitri et al. (2019). Based on these explanations, the first hypothesis can be proposed like this.

$\mathrm{H}_{1}$ : Depositor loyalty in the bank will be positively affected by perceived value

Service quality is the service conformity to what the firm promises to its customers (Parasuraman, Zeithaml, \& Berry, 1985). By referring to this statement, service quality measures something that depositors get based on bank promises. In their study, Hidayat et al. (2015) find that the bank can elevate depositors' loyalty by good service quality. This evidence is also in line with Alnaser et al. (2017) and Al-Areqi et al. (2018), who confirm this evidence. Based on these explanations, the second hypothesis can be proposed like this.

$\mathrm{H}_{2}$ : Depositor loyalty in the bank will be positively affected by service quality.

\section{RESEARCH METHOD}

\subsection{Variable definition}

The variable employed consists of two kinds. First, the explanatory variable: perceived value and service quality. Second, the explained variable: depositor loyalty. The measure of depositor loyalty refers to Widowati \& Tsabita (2017). Meanwhile, the proxy of perceived value and service quality denotes Roic et al. (2006) and Tjiptono, Chandra, \& Diana (2004), respectively. 
- $\quad$ According to Widowati \& Tsabita (2017), depositor loyalty has three items, i.e., I always utilize this bank services (DL1); I want to suggest this to my working partner as the place of the financial transaction (DL2); unlike the others, this bank gives me something unique (DL3).

- $\quad$ According to Roic et al. (2006) and Tjiptono et al. (2004), perceived value and service quality have some dimensions and indicators. Moreover, they can be seen in Tables 2 and 3.

Table 2: The dimensions and items of perceived value

\begin{tabular}{|c|c|}
\hline Dimension & Item \\
\hline \multirow{4}{*}{$\begin{array}{l}\text { Functional } \\
\text { facility value }\end{array}$} & Facilities offered by this bank reinforce the transaction secret and privacy (FFV1) \\
\hline & The system in this bank has good order and working management (FFV2). \\
\hline & The waiting room for depositors to transact is large, modern, and spotless (FFV3). \\
\hline & The facilities can be professionally utilized (FFV4). \\
\hline \multirow{4}{*}{$\begin{array}{l}\text { Functional } \\
\text { personal } \\
\text { value }\end{array}$} & The employees know their job well (FPERV1). \\
\hline & The knowledge of employees is updated well (FPERV2). \\
\hline & The employees can provide valuable information (FPERV3). \\
\hline & $\begin{array}{l}\text { The information about the product offered by the employees is all-inclusive } \\
\text { (FPERV4). }\end{array}$ \\
\hline \multirow{4}{*}{$\begin{array}{l}\text { Functional } \\
\text { service value }\end{array}$} & The quality of this bank is verified well (FSV1) \\
\hline & This bank retains its quality continually (FSV2) \\
\hline & The quality of this bank is better than that of others (FSV3) \\
\hline & This bank always realize its promises (FSV4) \\
\hline \multirow{3}{*}{$\begin{array}{l}\text { Functional price } \\
\text { value }\end{array}$} & The interest payment for depositors is determined (FPRV1). \\
\hline & I am ready to pay for the bank service charges (FPRV2) \\
\hline & The total charges of this bank make me reasonably think (FPRV3). \\
\hline \multirow[t]{5}{*}{ Emotional value } & I am glad about the financial contract offered by this bank (EV1). \\
\hline & I am comfortable with bank services (EV2). \\
\hline & The employees of this bank give me a positive value (EV3). \\
\hline & The employees of this bank do not disturb me during the service (EV4). \\
\hline & Overall, I am relaxed with all the bank service (EV5). \\
\hline \multirow[t]{2}{*}{ Social value } & Society assumes the services of this bank is good (SV1) \\
\hline & My coming to this bank is assumed satisfactory by the people who recognize me (SV2) \\
\hline
\end{tabular}

Table 3: The dimensions and items of service quality

\begin{tabular}{|l|l|}
\hline Dimension & \multicolumn{1}{|c|}{ Item } \\
\hline Tangible & This bank has modern transaction devices (T1). \\
\cline { 2 - 3 } & The facilities owned by this bank are visually eye-catching (T2) \\
\cline { 2 - 3 } & The employees of this bank wear their uniforms neatly (T3). \\
\cline { 2 - 3 } & The services in this bank are written (T4). \\
\hline Empathy & The employees of this bank give special attention to me (EMP1). \\
\cline { 2 - 3 } & Banks have operating hours to make customers feel comfortable (EMP2). \\
\cline { 2 - 3 } & These bank employees pay special attention to their customers (EMP3). \\
\cline { 2 - 3 } & The employee of this bank prioritizes the interests of its customers (EMP4) \\
\cline { 2 - 3 } & The employees of this bank understand the unique needs of their customers (EMP5). \\
\hline Responsiveness & The employees of this bank inform me about when the services are given (RES1). \\
\cline { 2 - 3 } & The employees of this bank serve me quickly (RES2). \\
\cline { 2 - 3 } & The employees of this bank are always ready to assist me (RES3). \\
\cline { 2 - 3 } & The employees of this bank take their time to serve me (RES4). \\
\hline & This bank always fulfills its promises to me (REL1). \\
\cline { 2 - 2 } & This bank gives solutions to me (REL2). \\
\cline { 2 - 2 } & This bank gives the service to me according to the time established (REL3). \\
\cline { 2 - 2 } & \\
\hline
\end{tabular}


Table 3: The dimensions and items of service quality

\begin{tabular}{|l|l|}
\hline Dimension & \multicolumn{1}{|c|}{ Item } \\
\hline \multirow{3}{*}{ Assurance } & This bank put forward the accuracy to serve me (REL4). \\
\cline { 2 - 2 } & The employees of this bank try to make me believe its services (A1). \\
\cline { 2 - 2 } & I am safe to transact with this bank (A2). \\
\cline { 2 - 2 } & The employees of this bank are polite to me (A3) \\
\cline { 2 - 2 } & The employees of this bank can answer all of my questions (A4). \\
\hline
\end{tabular}

\subsection{Method to collect data}

The survey becomes the method to bring the data together. In this way, according to Hartono (2012), the distribution of questionnaires is essential. Furthermore, the 5 points of the Likert scale are used to quantify the reactions of customer loyalty and two dimensions of perceived value and service quality items

\subsection{Population and Samples}

The depositors of bank H at branch FA become the population (N) with their sum of 1000. The Slovin formula with the residual margin (RM) of 5\% is utilized to decide the sample size (SS) by mentioning Suliyanto (2009). This formula can be seen in the first equation.

$S S=\frac{N}{1+N \cdot R M^{2}}$

By this formula, the sample size is $\frac{1,000}{1+1,000(0.05 * 0.05)}=285,71 \approx 286$. Then, the depositors becoming the sample are occupied by a simple random sampling method. Unfortunately, the total depositors participating in this survey are only 80 people. Hence, the response rate is $27.97 \%$. This rate is enough because of higher than $20 \%$, as explained by Sugiyanto, Nahartyo, Misra, Bastian, Hartono, Saputro, Sholihin, Sivilokonom, Almahendra, Winardi, Rostiani, Warsono, Ciptono, \& Widyaningsih (2018).

\subsection{Method to analyze the data}

By referring to the number of respondents of 60 , this study uses the structural equation model based on variance to analyze the data. This model can be found in Figure 1, as shown below.

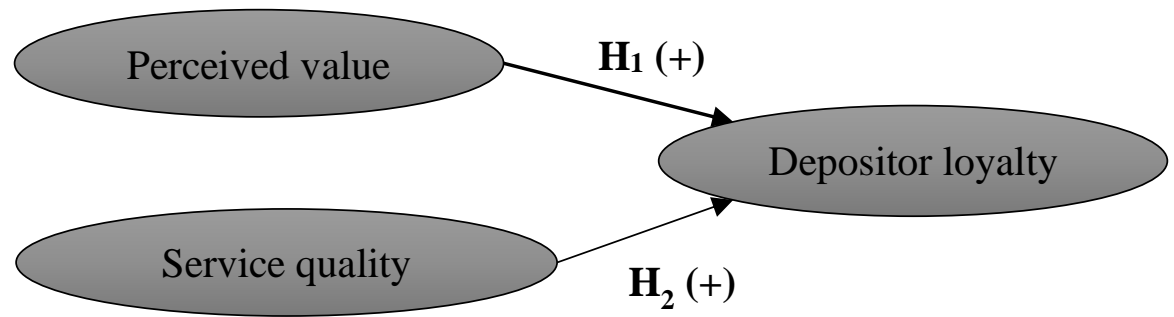

Figure 1: Research Model

The confirmatory factor analysis (CFA) and Cronbach Alpha (CA) analysis are utilized to test validity and reliability, one to one. The CFA attempts to know how accurate the answers of the respondents. To be precise, the loading factor of items should be higher than the cut-off point of 0.5 (Ghozali 2008). Meanwhile, the CA analysis intends to detect the consistency of respondents to answer the indicators. To be consistent, the CA coefficient of valid indicators has to be bigger than the cut-off value of 0.6 (Ghozali, 2006). 


\section{RESULT AND DISCUSSION}

\subsection{The demographic properties of respondents}

Table 4 presents the demographic properties of the respondents joining this survey. They cover gender, age, duration to be a depositor, and occupation. Moreover, the frequency and its percentage are used to describe them.

Table 4: The demographic property of the respondents joining this online survey

\begin{tabular}{|c|c|c|c|}
\hline $\begin{array}{l}\text { The demographic } \\
\text { property }\end{array}$ & Description & Frequency & Percentage \\
\hline \multirow[t]{3}{*}{ Gender } & Male & 30 & $37.50 \%$ \\
\hline & Female & 50 & $62.50 \%$ \\
\hline & Total & 80 & $100.00 \%$ \\
\hline \multirow[t]{5}{*}{ Age } & $18-20$ & 15 & $18.75 \%$ \\
\hline & $21-30$ & 20 & $25.00 \%$ \\
\hline & $31-40$ & 25 & $31.25 \%$ \\
\hline & $61-70$ & 20 & $25.00 \%$ \\
\hline & Total & 80 & $100.00 \%$ \\
\hline \multirow[t]{4}{*}{$\begin{array}{l}\text { Duration to be the } \\
\text { depositor }\end{array}$} & $\begin{array}{l}\text { Between one and three } \\
\text { years }\end{array}$ & 22 & $27.50 \%$ \\
\hline & $\begin{array}{l}\text { Between three and five } \\
\text { years }\end{array}$ & 18 & $22.50 \%$ \\
\hline & Over five years & 40 & $50.00 \%$ \\
\hline & Total & 80 & $100.00 \%$ \\
\hline \multirow[t]{3}{*}{ Occupation } & Employee & 20 & $25.00 \%$ \\
\hline & Business owner & 60 & $75.0 \%$ \\
\hline & Total & 80 & $100.00 \%$ \\
\hline
\end{tabular}

\subsection{The test result of validity and reliability}

After removing invalid items, the final test result of the dimension of perceived value's validity and reliability is displayed in Table 5. In this table, the item loading factor is between 0.622 and 0.996 , which is higher than 0.5 . Hence, the validity test is already reached. The Cronbach $\alpha$ coefficient of accurate items is from 0.675 to 0.990 , which is above 0.6 . Therefore, the reliability test is already attained.

Table 5: The loading factor and Cronbach Alpha of items of six dimensions of perceived value

\begin{tabular}{|c|l|l|c|}
\hline \multirow{2}{*}{ Dimension } & Item & $\begin{array}{l}\text { Loading } \\
\text { factor }\end{array}$ & \multirow{2}{*}{$\begin{array}{c}\text { Cronbach } \\
\text { Alpha }\end{array}$} \\
\hline \multirow{2}{*}{$\begin{array}{c}\text { Functional } \\
\text { facility value }\end{array}$} & FFV1 & 0.996 & \multirow{2}{*}{0.990} \\
\cline { 2 - 3 } & FFV2 & 0.956 & \multirow{2}{*}{} \\
\cline { 2 - 3 } & FFV3 & 0.996 & \multirow{2}{*}{0.940} \\
\cline { 2 - 3 } & FFV4 & 0.996 & \multirow{2}{*}{} \\
\hline \multirow{2}{*}{$\begin{array}{c}\text { Functional } \\
\text { personal } \\
\text { value }\end{array}$} & FPERV1 & 0.989 & \multirow{2}{*}{0.793} \\
\cline { 2 - 3 } $\begin{array}{c}\text { Functional } \\
\text { service value }\end{array}$ & FPERV2 & 0.875 & \\
\cline { 2 - 3 } & FPERV4 & 0.925 & \\
\cline { 2 - 3 } & FSV1 & 0.924 & \\
\cline { 2 - 3 } & FSV2 & 0.636 & 0.818 \\
\hline
\end{tabular}


Table 5: The loading factor and Cronbach Alpha of items of six dimensions of perceived value

\begin{tabular}{|c|c|c|c|}
\hline Dimension & Item & $\begin{array}{l}\text { Loading } \\
\text { factor }\end{array}$ & $\begin{array}{l}\text { Cronbach } \\
\text { Alpha }\end{array}$ \\
\hline \multirow[t]{2}{*}{ price value } & FPRCV2 & 0.818 & \\
\hline & FPRCV3 & 0.864 & \\
\hline \multirow{3}{*}{$\begin{array}{l}\text { Emotional } \\
\text { value }\end{array}$} & EV1 & 0.924 & \multirow[t]{3}{*}{0.675} \\
\hline & EV2 & 0.924 & \\
\hline & EV3 & 0.748 & \\
\hline \multirow[t]{2}{*}{ Social Value } & SV1 & 0.898 & \multirow[t]{2}{*}{0.759} \\
\hline & SV2 & 0.898 & \\
\hline
\end{tabular}

When examining the validity and reliability of service quality, fortunately, we find that all the service quality dimension items are valid and reliable. This circumstance happens because all loading factor is between 0.635 and 0.962, which is higher than 0.5, and the Cronbach Alpha is from 0.844 until 0.951, which is above 0.6 (see Table 6).

Table 6: The loading factor and Cronbach Alpha of items of five dimensions of service quality

\begin{tabular}{|c|c|c|c|}
\hline Dimension & Item & $\begin{array}{l}\text { Loading } \\
\text { factor }\end{array}$ & $\begin{array}{l}\text { Cronbach } \\
\text { Alpha }\end{array}$ \\
\hline \multirow[t]{4}{*}{ Tangible } & $\mathrm{T} 1$ & 0.911 & \multirow[t]{4}{*}{0.951} \\
\hline & $\mathrm{T} 2$ & 0.911 & \\
\hline & T3 & 0.962 & \\
\hline & $\mathrm{T} 4$ & 0.945 & \\
\hline \multirow[t]{5}{*}{ Empathy } & EMP1 & 0.939 & \multirow[t]{5}{*}{0.935} \\
\hline & EMP2 & 0.900 & \\
\hline & EMP3 & 0.635 & \\
\hline & EMP4 & 0.879 & \\
\hline & EMP5 & 0.949 & \\
\hline \multirow[t]{4}{*}{ Reliability } & REL1 & 0.901 & \multirow[t]{4}{*}{0.896} \\
\hline & REL2 & 0.906 & \\
\hline & REL3 & 0.788 & \\
\hline & REL4 & 0.910 & \\
\hline \multirow[t]{4}{*}{ Responsiveness } & RES1 & 0.844 & \multirow[t]{4}{*}{0.844} \\
\hline & RES2 & 0.831 & \\
\hline & RES3 & 0.829 & \\
\hline & RES4 & 0.891 & \\
\hline \multirow[t]{4}{*}{ Assurance } & A1 & 0.878 & \multirow[t]{4}{*}{0.856} \\
\hline & A2 & 0.861 & \\
\hline & A3 & 0.817 & \\
\hline & A4 & 0.820 & \\
\hline
\end{tabular}

When testing the validity and reliability of depositor loyalty, we obtain that the loading factor of DL1, DL2, and DL3 exceeds 0.5, i.e., 0.946, 0.967, and 0.982. Also, Cronbach Alpha for these items is 0.963, higher than 0.6 (see Table 7). Because of this situation, the validity and reliability tests are confirmed. 
Table 7: The loading factor and Cronbach Alpha of items of depositor loyalty

\begin{tabular}{|c|c|c|}
\hline Item & $\begin{array}{l}\text { Loading } \\
\text { factor }\end{array}$ & $\begin{array}{l}\text { Cronbach } \\
\text { Alpha }\end{array}$ \\
\hline DL1 & 0.946 & \multirow[t]{3}{*}{0.963} \\
\hline DL2 & 0.967 & \\
\hline DL3 & 0.982 & \\
\hline
\end{tabular}

\subsection{The estimation result of the research model}

Figure 2 below shows the estimation result of the structural equation model based on partial least square. In this figure, the probability value of the t-statistic of $\beta_{1}$ of 0.585 and $\beta_{2}$ of 0.355 is less than 0.000 . Because these values are below the significance level of $5 \%$, the positive impact of perceived value and service quality on depositor loyalty is present.

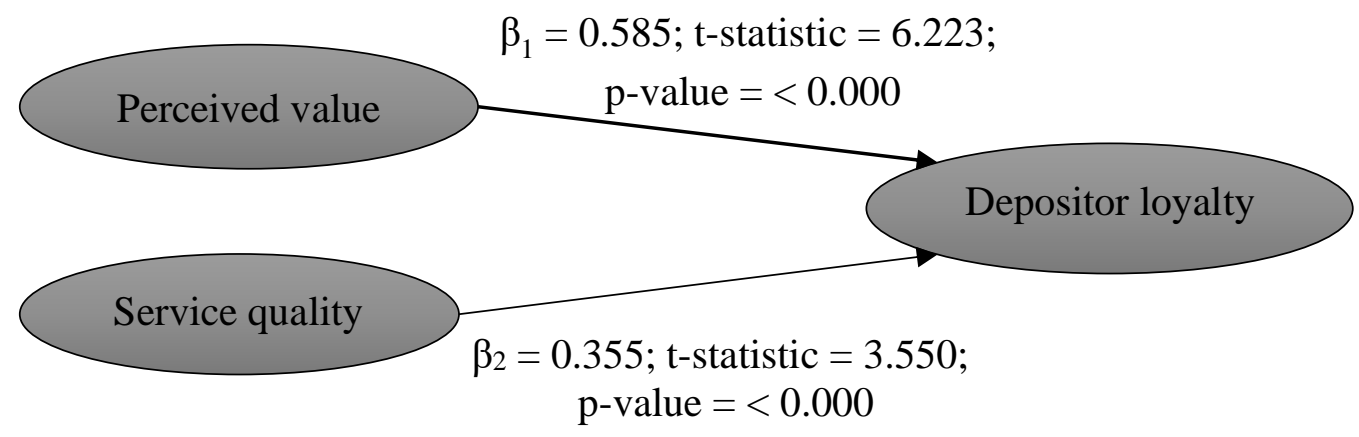

Figure 2: The estimation result of structural equation model based on partial least square Source: Modified Output of Warp PLS 7.0

\subsection{Discussion}

From the research hypothesis examination, it is proven that perceived value positively influences depositor loyalty. The acceptance of this hypothesis supports the study result of Jumanev et al. (2012), Hasan et al. (2014), Rahi \& Ghani (2016), Mukerjee (2018), and Fitri et al. (2019). In this study context, to get the depositors' dedication, the bank needs to pay attention to the facility, employee, service, price, emotional, social values with a low valid and reliable agreeing response, that is lower than $60 \%$, as shown in Tables 8, 9, 10, 11, and 12.

- The survey associated with functional facility value displays that the agreeing response percentage is between $28.75 \%$ and 81.250 , considered low to high (see Table 8 ). The small is on FFV1, FFV2, and FFV4. Therefore, the bank must create them to support depositors to transact (FFV1) and be effortlessly utilized by depositors (FFV4). Additionally, the bank essentially provides an excellent operating system to serve depositors (FFV2).

Table 8: The number of agreeing on responses to the functional facility value

\begin{tabular}{|c|c|c|c|c|}
\hline Response & FFV1 & FFV2 & FFV3 & FFV4 \\
\hline 1 (strongly disagree) & 0 & 3 & 0 & 0 \\
\hline 2 (disagree) & 0 & 8 & 9 & 0 \\
\hline 3 (neutral) & 57 & 46 & 15 & 57 \\
\hline 4 (agree) & 4 & 13 & 46 & 23 \\
\hline 5 (strongly agree) & 19 & 10 & 19 & 0 \\
\hline The total of the agreeing response (4 and 5) & 23 & 23 & 65 & 23 \\
\hline
\end{tabular}




\begin{tabular}{|c|c|c|c|c|}
\hline Total respondents & 80 & 80 & 80 & 80 \\
\hline Percentage of agreeing response & $28.75 \%$ & $28.75 \%$ & $81.25 \%$ & $28.75 \%$ \\
\hline
\end{tabular}

Source: Processed from the primary data

- The survey associated with functional personal value illustrates that the agreeing response percentage is between $17.50 \%$ and $28.75 \%$, considered low (see Table 9 ). Therefore, the bank should train staff members and equip them with valuable information to serve depositors.

Table 9: The number of agreeing on responses to the functional personal value

\begin{tabular}{|c|c|c|c|}
\hline Response & FPERV1 & FPERVV2 & FPERV4 \\
\hline 1 (strongly disagree) & 0 & 0 & 0 \\
\hline 2 (disagree) & 0 & 0 & 0 \\
\hline 3 (neutral) & 57 & 57 & 66 \\
\hline 4 (agree) & 13 & 23 & 4 \\
\hline 5 (strongly agree) & 10 & 0 & 10 \\
\hline The total of the agreeing response (4 and 5) & 23 & 23 & 14 \\
\hline Total respondents & 80 & 80 & 80 \\
\hline Percentage of agreeing response & $28.75 \%$ & $28.75 \%$ & $17.50 \%$ \\
\hline
\end{tabular}

Source: Processed from the primary data

- The survey associated with functional service value demonstrates that the agreeing response percentage is $28.75 \%$ to $30.00 \%$, considered low (see Table 10 ). Therefore, the bank should rebuild its quality so that depositors can trust it.

Table 10: The number of agreeing on responses to the functional service value

\begin{tabular}{|c|c|c|c|c|}
\hline Response & FSV1 & FSV2 & FSV3 & FSV4 \\
\hline 1 (strongly disagree) & 0 & 3 & 0 & 0 \\
\hline 2 (disagree) & 0 & 8 & 9 & 0 \\
\hline 3 (neutral) & 57 & 46 & 47 & 57 \\
\hline 4 (agree) & 4 & 13 & 24 & 23 \\
\hline 5 (strongly agree) & 19 & 10 & 0 & 0 \\
\hline The total of the agreeing response (4 and 5) & 23 & 23 & 24 & 23 \\
\hline Total respondents & 80 & 80 & 80 & 80 \\
\hline Percentage of agreeing response & $28.75 \%$ & $28.75 \%$ & $30 \%$ & $28.75 \%$ \\
\hline
\end{tabular}

Source: Processed from the primary data

- The survey associated with emotional value expresses that the agreeing response percentage is between $28.75 \%$ and $52.50 \%$, considered low (see Table 11). Therefore, the bank has to make virtuous financial contact for depositors (EV1) and depositors comfortable with the provided service (EV2). Besides, the bank must train the staff members to positively value depositors (EV3).

Table 11: The number of agreeing on responses to the emotional value

\begin{tabular}{|c|c|c|c|}
\hline Response & EV1 & EV2 & EV3 \\
\hline 1 (strongly disagree) & 0 & 0 & 0 \\
\hline 2 (disagree) & 0 & 0 & 0 \\
\hline 3 (neutral) & 57 & 57 & 38 \\
\hline 4 (agree) & 13 & 13 & 42 \\
\hline 5 (strongly agree) & 10 & 10 & 0 \\
\hline The total of the agreeing response (4 and 5) & 23 & 23 & 42 \\
\hline
\end{tabular}




\begin{tabular}{|l|c|c|c|}
\hline \multicolumn{1}{|c|}{ Total respondents } & 80 & 80 & 80 \\
\hline Percentage of agreeing response & $28.75 \%$ & $28.75 \%$ & $52.50 \%$ \\
\hline
\end{tabular}

Source: Processed from the primary data

- $\quad$ The survey associated with social value shows that the agreeing response percentage is $76.25 \%$ until $81.50 \%$, considered high (see Table 12 ). It means the bank already effectively implements functional social value.

Table 12: The number of agreeing on responses to the social value

\begin{tabular}{|c|c|c|}
\hline Response & SV1 & SV2 \\
\hline 1 (strongly disagree) & 6 & 0 \\
\hline 2 (disagree) & 1 & 1 \\
\hline 3 (neutral) & 18 & 14 \\
\hline 4 (agree) & 34 & 22 \\
\hline 5 (strongly agree) & 27 & 43 \\
\hline The total of the agreeing response (4 and 5) & 61 & 65 \\
\hline Total respondents & 80 & 80 \\
\hline Percentage of agreeing response & $76.25 \%$ & $81.25 \%$ \\
\hline
\end{tabular}

Source: Processed from the primary data

From the research hypothesis examination, it is proven that service quality positively influences depositor loyalty. The acceptance of this hypothesis supports the study result of Hidayat et al. (2015), Alnaser et al. (2017), and AlAreqi et al. (2018). In this study context, to get the depositors' dedication, the bank needs to pay attention to the list of valid and reliable service quality dimension indicators with the inadequate agreeing response $(<60 \%)$ (see Table 13). In this table, the intended answers are REL3, RES1, RES2, RES3, and A4, ranged from $42.50 \%$ to $57.5 \%$. Hence, the bank should be on time to give the service to the depositors (REL3), train and equip the staff members with the product knowledge to provide a speedy response to serve the depositors (RES1, RES2, RES3, and A4).

Table 13: The number of agreeing on responses to items of reliability, responsiveness, and assurance

\begin{tabular}{|l|c|c|c|c|c|}
\hline \multicolumn{1}{|c|}{ Response } & REL3 & RES1 & RES2 & RES3 & A4 \\
\hline 1 (strongly disagree) & 0 & 0 & 0 & 0 & 0 \\
\hline 2 (disagree) & 3 & 0 & 0 & 2 & 0 \\
\hline 3 (neutral) & 33 & 36 & 34 & 44 & 42 \\
\hline 4 (agree) & 25 & 23 & 18 & 14 & 17 \\
\hline 5 (strongly agree) & 19 & 21 & 28 & 20 & 21 \\
\hline The total of the agreeing response (4 and 5) & 44 & 44 & 46 & 34 & 38 \\
\hline Total respondents & 80 & 80 & 80 & 80 & 80 \\
\hline Percentage of agreeing response & $55 \%$ & $55.00 \%$ & $57.50 \%$ & $42.50 \%$ & $47.50 \%$ \\
\hline
\end{tabular}

Source: Processed from the primary data

\section{CONCLUSION}

This research aims to investigate and analyze the effect of perceived value and service quality on depositor loyalty. By hypothesis testing on the perception of 60 respondents as the sample, this study successfully proves that a positive impact of two determinants is available. This research is not faultless because of owning several borders: the two determining variables and the few respondents as samples consisting of 60 depositors.

a. Regarding the first issue, the next scholars can add the bank social responsibility, bank image, depositor satisfaction, commitment, trust, switching cost, relationship marketing to their model as the other determinants. 
b. Regarding the second issue, the next scholars can use all depositors in some branches for the same bank locating in a city or some cities to be the population. Therefore, they will own big sample size. By large sample, the result of hypothesis testing will be more precise.

\section{References}

Al-Areqi, B., Al-Hadeq, A., \& Mutahar, A. (2018). Determinants of customer loyalty in Yemen banking industry. IOSR Journal of Business and Management, 20(9), 1-12.

Alnaser, F. M., Ghani, M. A., Rahi, S., Mansour, M., \& Abed, H. (2017). Determinants of customer loyalty: The role of service quality, customer satisfaction, and bank image of Islamic banks in Palestine. International Journal of Economics \& Management Sciences, 6(5), 1-4.

Chatterjee, D., \& Kamesh, A. V. (2019). Relationship marketing: Impact on bank customers' satisfaction. International Journal of Recent Technology and Engineering, 8(4), 8754-8760.

Fitri, L. E., Basrib, Y. Z., \& Maryanti, T. (2019). The mediating effect of customer satisfaction on customer loyalty: A study of Islamic banks in Indonesia. Journal of Islamic Finance, 8(1), 048-059.

Ghozali, I. (2006). Aplikasi analisis multivariate dengan program SPSS (4 ed.). Semarang: Badan Penerbit Universitas Diponegoro.

Ghozali, I. (2008). Structural Equation Modeling: Metode Alternatif dengan Partial Least Square (2 ed.). Semarang: Badan Penerbit Universitas Diponegoro.

Hartono, J. (2012). Metodologi Penelitian Bisnis: Salah Kaprah \& Pengalaman-Pengalaman (5 ed.). Yogyakarta: Badan Penerbit Fakultas Ekonomi Universitas Gadjah Mada.

Hasan, H., Kiong, T. P., \& Ainuddin, R. A. (2014). Effects of perceived value and trust on customer loyalty towards foreign banks in Sabah, Malaysia. Global Journal of Emerging Trends in e-Business, Marketing, and Consumer Psychology, 1(2), 137-153.

Hidayat, R., Akhmad, S., \& Mahmud, M. (2015). Effect of service quality, customer trust, and customer religious commitment on customer satisfaction and loyalty of Islamic Banks in East Java. Al-Iqtishad, 7(2), $151-164$

Husnan, S. (2015). Dasar-Dasar Teori Portfolio dan Analisis Sekuritas (5 ed.). Yogyakarta: UPP STIM YKPN.

Jumanev, M., Kumar, D., \& Hanaysha, J. R. (2012). Impact of relationship marketing on customer loyalty in banking sector. Far East Journal of Psychology and Business, 6(3), 36-55.

Kertajaya, H. (2007). Hemawan Kertajaya on Brand: Seri 9 Elemen Marketing. Bandung: Penerbit Mizan.

Koupai, M., Alipourdarvish, Z., \& Sardar, S. (2015). Effects of trust and perceived value on customer loyalty by mediating role of customer satisfaction and mediating role of customer habit (Case study: Agricultural internet bank customers in Tehran). Advanced Social Humanities and Management, 2(1), 102-112.

Mukerjee, K. (2018). The impact of brand experience, service quality, and perceived value on word of mouth of retail bank customers: Investigating the mediating effect of loyalty. Journal of Financial Services Marketing, 23, 12-24.

Narotama, A. (2019). The effect of service quality on customer loyalty with brand images and customer satisfaction as mediation. Jurnal Manajemen \& Kewirausahaan, 7(1), 86-93.

Nursiana, A. (2011). Pengaruh kualitas layanan terhadap loyalitas nasabah dengan intermediasi kepuasan nasabah dan nilai yang dirasakan nasabah. Ultima Management, 3(1), 1-15.

Parasuraman, A., Zeithaml, V., \& Berry, L. L. (1985). A conceptual model of service quality and its implications for future research. The Journal of Marketing, 49(4), 41-50.

Rahi, S., \& Ghani, M. A. (2016). Internet banking, customer perceived value, and loyalty: The role of switching costs. Journal of Accounting \& Marketing, 5(4), 1-7.

Setiawan, A. M., Kusumawati, A., \& Mawardi, M. (2018). The impact of relationship marketing and service quality on customer satisfaction and customer loyalty (Study on customers of BNI Malang branch office). Jurnal Administrasi Bisnis, 59(1), 163-170.

Sugiyanto, C., Nahartyo, E., Misra, F., Bastian, I., Hartono, J., Saputro, J. A, Sholihin, M., Sivilokonom, N. I., Almahendra, R., Winardi, R. D., Rostiani, R., Warsono, S., Ciptono, W. S., \& Widyaningsih, Y. A. (2018). Strategi Penelitian Bisnis. (J. Hartono, Ed.) Yogyakarta: Penerbit ANDI.

Suliyanto. (2009). Metode Riset Bisnis. Yogyakarta: Penerbit ANDI.

Taswan, T. (2010). Manajemen Perbankan: Konsep \& Aplikasi (2 ed.). Yogyakarta: STIE YKPN.

Tjiptono, F., Chandra, Y., \& Diana, A. (2004). Marketing Scale. Yogyakarta: Penerbit ANDI.

Widowati, R., \& Tsabita, F. (2017). The influence of experiential marketing on customer loyalty through customer satisfaction as intervening variable (Study at the House of Raminten Restaurant in Yogyakarta Indonesia). Jurnal Manajemen Bisnis, 8(2), 163-180. 